\title{
LA-ICP-MS analysis of fluid inclusions: contamination effects challenging micro-analysis of elements close to their detection limit
}

\author{
Journal Article \\ Author(s): \\ Schlöglova, Katerina; Wälle, Markus; Heinrich, Christoph A. (D) \\ Publication date: \\ 2017-05 \\ Permanent link: \\ https://doi.org/10.3929/ethz-b-000255474
}

Rights / license:

In Copyright - Non-Commercial Use Permitted

Originally published in:

Journal of Analytical Atomic Spectrometry 32(5), https://doi.org/10.1039/c7ja00022g

Funding acknowledgement:

146651 - Mineral resources: Physical dynamics driving chemical enrichment of rare metals (SNF) 
This is the Green Open Access version of: Schlöglova, K., Wälle, M., Heinrich, C.A., 2017. LA-ICP-MS analysis of fluid inclusions: Contamination effect challenging micro-analysis of elements close to their detection limit. Journal of Analytical Atomic Spectrometry, 32, 1052-1063. Original publication can be found on https://doi.org/10.1039/C7JA00022G

\title{
LA-ICP-MS analysis of fluid inclusions: Contamination effects challenging micro-analysis of elements close to their detection limit
}

\author{
Katerina Schlöglova1, Markus Wälle1,2, Christoph A. Heinrich1,3 \\ 1 ETH Zurich, Institute of Geochemistry and Petrology, Department of Earth Sciences, \\ Clausiusstrasse 25, 8092 Zurich, Switzerland. Corresponding author, e-mail: \\ katerina.schloglova@erdw.ethz.ch \\ 2 Present address: CREAIT, CRC and CFI Services (CCCS), Memorial University of Newfoundland, St. \\ John's, NL A1C 5S7, Canada \\ ${ }^{3}$ Faculty of Mathematics and Natural Sciences, University of Zurich, 8093 Zurich, Switzerland
}

\begin{abstract}
This paper presents a practical guide to an optimized analytical procedure for the reliable quantification of trace element concentrations in fluid inclusions hosted by natural minerals, using laser ablation inductively coupled plasma mass spectrometry (ICP-MS). With the improved sensitivities of modern ICP-MS instrumentation, more stringent guidelines for cleaning and contaminant reduction become decisive in extending the limits of trace element analysis, particularly for dilute fluids and smaller inclusions investigated by highly sensitive sector field ICP-MS. We have identified three sources of contamination that limit the recording and quantification of low-count signals, namely: (1) The carrier gas quality that affects the continuous instrumental background. (2) The material and cleanliness of the ablation cell, connection tubing material, and sampler and skimmer cone, all of which may cause a falsely elevated signal during ablation. (3) Contamination of the sample surface during its preparation and from the deposition of previously ablated material, including aerosols produced during extended ablation of an ICP-MS tuning material. Contamination from these sources can overlap with the host mineral and with the fluid inclusion signal. Based on extensive test experiments, we propose a workflow that allows minimization of these contamination contributions and optimizes representative sampling and quantification of fluid inclusion data. For example, Au and S in low-density vapor-dominated inclusions may be quantified down to a few ng.g${ }^{1}$ and a few hundred $\mu \mathrm{g} \cdot \mathrm{g} \cdot{ }^{-1}$, respectively.
\end{abstract}

\section{Introduction}

The determination of trace element composition of geological fluids is important for the understanding of hydrothermal mass transport in the Earth`s crust, including the enrichment of trace metals in ore deposits. ${ }^{1-9}$ Laser ablation inductively coupled plasma mass spectrometry (LA-ICP-MS) is a rapid, highly sensitive, and well established analytical method, widely used for quantification of low-level element concentrations in geological samples. ${ }^{10,11}$ It is now the preferred method for studying microscopic fluid and melt inclusions - droplets of paleo-fluids and melts preserved in 
various minerals. ${ }^{12-14}$ Such inclusions are trapped as originally homogeneous micro-samples of fluid or melt, but may separate into several phases during cooling and exhumation to the Earth's surface. ${ }^{15}$ UV lasers, such as the 193-nm ArF-Excimer, allow controlled ablation of a single inclusion, thereby re-integrating the bulk composition of the original inclusion.14,16-18 Modern ICP-MS systems, notably single-collector sector-field (SF-ICP-MS) instruments, have greatly enhanced sensitivities for a wide range of elements. ${ }^{19,20}$ In our attempts to make full use of this increased sensitivity and to reach correspondingly lower limits of detection (LOD), new challenges of instrument and sample contamination have become apparent. These are particularly critical in the microanalysis of fluid inclusions because these are samples of small finite mass. In addition, transient signals commonly require deconvolution of element contributions from the inclusion and from the host mineral. Several sources of contamination currently limit advances in hydrothermal geochemistry for natural samples, as well as in experimental studies using synthetic inclusions.

This paper focuses on simultaneous analysis of gold and sulfur in fluid inclusions, but similar issues have been observed for a range of other elements, such as $\mathrm{Cl}$ and $\mathrm{Br}^{8,21}$, or $\mathrm{Sn}$, and $\mathrm{Hg}$. Signal validity must be critically evaluated for all elements, especially if they are close to their limit of detection. Gold and sulfur are important for understanding the commonly coupled transport of these two elements in magmatic-hydrothermal fluids: sulfide acts as a complexing ligand enhancing gold solubility in high-temperature crustal fluids and sulfide removal may trigger gold precipitation in ore deposits. $^{22-25}$ Quantification of sulfur by ICP-MS is particularly challenging for three reasons: Firstly, sulfur as an anion component in hydrothermal systems has a low formation yield for positive ions because the ionization potential of $\mathrm{S}^{+}\left(999.6 \mathrm{~kJ} \cdot \mathrm{mol}^{-1}\right)$ is close to that of $\mathrm{Ar}^{+}\left(1520.6 \mathrm{~kJ} \cdot \mathrm{mol}^{-1}\right)$. Secondly, there is a high background on the abundant $S$ isotopes $\left({ }^{32} S\right.$ and ${ }^{34} \mathrm{~S}$ ) due to polyatomic interference from abundant $16 \mathrm{O}^{16} \mathrm{O}^{+}$and ${ }^{16} \mathrm{O}^{18} \mathrm{O}^{+}$, respectively, formed in the ICP from ambient air and impurities in the plasma gases. Medium mass resolution of the ICP-SF-MS can resolve this interference, but it reduces overall sensitivity by an order of magnitude. ${ }^{26}$ This severely affects the limit of detection of all other trace elements, including Au. ${ }^{21,26}$ Thirdly, sulfur is ubiquitous in the environment, giving rise to several contamination sources. ${ }^{21,26-28}$ Despite these obstacles, determination of sulfur has been achieved by Q-ICP-MS and SF-ICP-MS, using samples of natural liquid and brine inclusions. ${ }^{21,26}$ Gold has been successfully analyzed by LA-ICP-MS in various types of synthetic inclusions from experimental runs that typically contain a few to tens of $\mu \mathrm{g} \cdot \mathrm{g}^{-1} \mathrm{Au} \cdot{ }^{29-32} \mathrm{Gold}$ can also be present at $\mu \mathrm{g} \cdot \mathrm{g}^{-1}$ levels in natural fluids but it is generally close to the detection limit.3,33${ }^{36}$ Even though $\mathrm{Au}$ is expected to be enriched in S-rich vapor ${ }^{3} 37$, the reduced amount of an analyte in low-density vapor inclusions produces shorter signals, which are subject to larger uncertainties regarding representative quantification by sequential sampling of the signal ${ }^{18,20}$. Counting statistics is the major source of uncertainty for quantification of elements close to the analytical detection limit, requiring Poisson statistics ${ }^{18,38,39}$ rather than a Gaussian approach ${ }^{11}$. Moreover, a potential bias may result in overestimation of average element concentrations in fluid inclusion assemblages, where only some inclusions provide detectable signals even if the bulk composition of all inclusions is expected to be similar. This issue has been addressed in recent critical discussions ${ }^{36}$, including the possibility of summation of multiple transient signals to avoid such a bias in justified cases ${ }^{35}$.

Improving count numbers by greater instrument sensitivity is the most effective way to address these challenges. However, using routine laboratory conditions and a modern highly-sensitive LASF-ICP-MS set-up ${ }^{20}$, we have encountered several contamination issues that were previously less severe or undetected with our less-sensitive quadrupole ICP-MS. These entail: (1) high Au and S gas blank levels exceeding the increase in instrument sensitivity; (2) elevation of Au and S signals during 
host ablation while ablating minerals and materials, even if these are $\mathrm{Au}$ - and S-free; and (3) strongly elevated signals of $\mathrm{Au}, \mathrm{S}$, and other elements starting at the onset of host ablation. Systematic evaluation of these issues brought our attention to the type and quality of materials used in the laboratory and their cleanliness. We have identified several sources of contamination. This includes sample surface contamination, carrier gas quality, the materials and internal surfaces of ablation cells and aerosol transport tubes, and the material and condition of the sampler and skimmer cones of the ICP-MS. A clear cleaning and optimization strategy proposed below can minimize these contamination effects and allow new insights into the composition of particularly small or dilute inclusions in different host minerals including quartz, topaz and beryl.

\section{Instrument setup}

\subsection{Analytical conditions}

The 193-nm ArF-Excimer laser ablation system at the ETH Zurich (prototype to the Geolas system, Coherent, Germany) can be alternatively coupled to a Perkin Elmer 6100 DRC quadrupole ICP-MS40 or to a fast-scanning sector-field ICP-MS (Element XR, Thermo Scientific, Germany) ${ }^{26}$. The latter combination was used for all ablation experiments reported here, but results were also compared to previously published measurements using the quadrupole instrument. Optimization of the ICP-MS was carried out using a newly prepared trace element-free silicate glass doped with Th and U. All analyses were referenced against an external standard, NIST SRM 610, ablating pits of 40 ?m in diameter for $\sim 30 \mathrm{~s}$ before and after each block of 18 analyses of unknown samples. For the carrier gas, we used $1.0 \mathrm{~L} \cdot \mathrm{min}^{-1}$ of 5.0 or 6.0 grade helium, merged with $0.75-0.95 \mathrm{~L} \cdot \mathrm{min}^{-1} 6.0$ grade argon downstream from the sample chamber ${ }^{41,42}$. A repetition rate of $10 \mathrm{~Hz}$ was used for the ablation of the tuning and standard materials and quartz, and $20 \mathrm{~Hz}$ for that of topaz and beryl.

Three types of custom-made sample chambers were tested: a rhomb-shaped stainless steel cell and an identical aluminum cell (a), and a round all-glass cell (b) that was initially designed by $\mathrm{K}$. Kouzmanov for analysis of complex sulfides ${ }^{43}$. They all have a volume of $\sim 1 \mathrm{~cm}^{3}$ and are covered by an anti-reflection coated silica glass window placed on a thin rubber or Teflon seal. Several tubing materials for aerosol transport between the sample chamber and the mass spectrometer were tested: polyamide (Legris, France), PVC (Nalgene ${ }^{\mathrm{TM}}$, Thermo Fisher Scientific Inc., USA), Tygon(C) (SaintGobain, UK), Teflon (C) (PTFE) and fluorinated ethylene propylene (FEP; both Rotilabo®, Carl Roth

$\mathrm{GmbH}$, Germany). The sampling of fluid inclusions was carried out using an iris aperture allowing gradual opening of the ablation pit using the GeoLas simultaneous UV/Vis imaging optics. Laterally homogenized UV irradiation assures complete ablation of the targeted inclusion and also allows cleaning of the sample surface by laser ablation (see section Sample surface). An overview of the instrumental set up is given in Table 1, which emphasizes the conditions found to be the most successful for fluid inclusion analysis. The absolute element concentrations of the fluid inclusions were calculated from the LA-ICP-MS signals using the Matlab-based SILLS program ${ }^{44}$ and included the limits of detection based on Pettke et al. ${ }^{18}$. 
Table 1 Instrumental parameters used for successful LA-SF-ICP-MS fluid inclusion analysis.

\begin{tabular}{|c|c|}
\hline Laser type & ETH Geolas prototype ${ }^{40}$ ArF-Excimer (Coherent, Germany) \\
\hline Laser wavelength & $193 \mathrm{~nm}$ \\
\hline Laser energy density & $10-22 \mathrm{~J} \cdot \mathrm{cm}^{-2}$ \\
\hline Laser repetition rate & $10 \mathrm{~Hz}$ (quartz), $20 \mathrm{~Hz}$ (topaz and beryl) \\
\hline Spot size & $10-120 \mu \mathrm{m}$, dynamic opening with iris aperture \\
\hline Ablation cell & $\begin{array}{l}\text { Custom-made round, glass, } 1 \mathrm{~cm}^{3} \text { volume } \\
\text { (In-house-built fast-washout rhomb-shape, aluminum or steel, } 1 \\
\mathrm{~cm}^{3} \text { ) }\end{array}$ \\
\hline Tubing connection & FEP or PTFE (Rotilabo®, Carl Roth GmbH, Germany), 3 m long \\
\hline ICP-MS & Element XR (Thermo Scientific, Bremen, Germany) \\
\hline MS type & Sector Field \\
\hline Sampler cone & Ni 1044530 (Thermo Scientific, Germany) \\
\hline Skimmer cone & Nickel (H) 856-72 (AHF Analysentechnik, Germany) \\
\hline Carrier gas & He, 6.0 or 5.0 grade (PanGas, Switzerland), $1.0 \mathrm{~L} \cdot \mathrm{min}^{-1}$ \\
\hline Sample gas & Ar, 6.0 grade, liquid (PanGas, Switzerland), $0.75-0.95 \mathrm{~L} \cdot \mathrm{min}^{-1}$ \\
\hline Plasma power & $1350-1550 \mathrm{~W}$ \\
\hline \multicolumn{2}{|c|}{$\begin{array}{r}\left.\mathrm{ThO}^{+} / \mathrm{Th}^{+} \text {oxide ratio (on Nist SRM 610,40 } \mu \text { m spot size, } 10 \mathrm{~Hz}, 12 \mathrm{~J} \cdot \mathrm{cm}^{2}\right) \\
<0.3 \%\left(<0.01 \% \text { for }{ }^{197} \mathrm{Au} \text { and }{ }^{181} \mathrm{Ta}^{16} \mathrm{O}^{+} \text {in }\right.\end{array}$} \\
\hline \multicolumn{2}{|c|}{ Intensity on NIST SRM $610\left(40 \mu \mathrm{m}\right.$ spot size, $\left.10 \mathrm{~Hz}, 12 \mathrm{~J} \cdot \mathrm{cm}^{2}\right)$ : } \\
\hline${ }^{23} \mathrm{Na}$ & $1 \cdot 10^{9} \mathrm{cps}\left(10,096 \mathrm{cps} \cdot \mu \mathrm{g}^{-1} \cdot \mathrm{g}^{*}\right)$ \\
\hline${ }^{197} \mathrm{Au}$ & $4 \cdot 10^{5}$ cps $\left(17,778 \mathrm{cps} \cdot \mu \mathrm{g}^{-1} \cdot \mathrm{g}^{*}\right)$ \\
\hline Gas blank on mass 34 & $2 \cdot 10^{5} \mathrm{cps}$ \\
\hline Gas blank on mass 197 & $2 \cdot 10^{1} \mathrm{cps}$ \\
\hline Isotopes measured & ${ }^{23} \mathrm{Na},{ }^{29} \mathrm{Si},{ }^{34} \mathrm{~S},{ }^{65} \mathrm{Cu},{ }^{133} \mathrm{Cs},{ }^{181} \mathrm{Ta},{ }^{197} \mathrm{Au}$ \\
\hline Dwell time per isotope & $20 \mathrm{~ms}\left(\right.$ exc. ${ }^{197} \mathrm{Au}: 200 \mathrm{~ms}$ ) \\
\hline Cycle time & $311 \mathrm{~ms}$ \\
\hline Settling time & 1-80 ms (depending on isotope) \\
\hline
\end{tabular}

${ }^{*}$ Sensitivity in cps per $\mu \mathrm{g} \cdot \mathrm{g}^{-1}$ of elements on NIST SRM 610 containing 99,050 $\mu \mathrm{g} \cdot \mathrm{g}{ }^{-1} \mathrm{Na}$ and $22.5 \mu \mathrm{g} \cdot \mathrm{g}$ ${ }^{1} \mathrm{Au}^{45}$.

\subsection{A new optimization material for contamination-free instrument tuning}

Traditionally, tuning of the ICP-MS is performed by extended ablation of a multi-element reference material, such as NIST SRM glasses. These glasses contain significant concentrations of numerous elements for external calibration, including $570 \mu \mathrm{g} \cdot \mathrm{g}^{-1} \mathrm{~S}^{26}$ and $22.5 \mu \mathrm{g} \cdot \mathrm{g}^{-1} \mathrm{Au}^{45}$ in the NIST SRM 610, and $450 \mu \mathrm{g} \cdot \mathrm{g}^{-1} \mathrm{~S}^{26}$ and $5.09 \mu \mathrm{g} \cdot \mathrm{g}^{-1} \mathrm{Au}^{45}$ in the NIST SRM 612. The total quantity of Au liberated during the extended ablation of such material (typically several minutes of tuning) exceeds the quantity of $\mathrm{Au}$ in the subsequently measured fluid inclusions by many orders of magnitude, so that even small fractions of aerosol remaining in the sample chamber can lead to measurable contamination and memory effects ${ }^{10,46}$.

To minimize these contamination effects, we prepared a new homogeneous material containing approximately $3000 \mu \mathrm{g} \cdot \mathrm{g}^{-1} \mathrm{Th}$ and $\mathrm{U}$ in an otherwise trace element-free matrix of Na-Ca-Mg-Alsilicate glass. With a prepared $\mathrm{Th} / \mathrm{U}$ concentration ratio close to 1 , the similar ionization energies ( $\mathrm{Th}^{+}: 587 \mathrm{~kJ} \cdot \mathrm{mol}^{-1} ; \mathrm{U}^{+}: 597.6 \mathrm{~kJ} \cdot \mathrm{mol}^{-1}$ ) and the similar isotopic abundance of the dominant masses ${ }^{232} \mathrm{Th}$ and $238 \mathrm{U}$ (both $>99 \%$ of the respective element), the intensity ratio is expected to be close to 1 if ionization is complete ${ }^{47}$. Deviations below 1 are due to the formation of refractory $\mathrm{ThO}^{+}$oxide during atomization. Monitoring the $\mathrm{ThO}^{+} / \mathrm{Th}^{+}$intensity ratio is therefore used to optimize the ICP- 
MS operating parameters (e.g. gas flow rates, torch position, and plasma power) to an optimum sensitivity on $\mathrm{U}^{+}$but acceptably low oxide rates based on $\mathrm{ThO}^{+} / \mathrm{Th}^{+}$.

To prepare this tuning material, powders of $\mathrm{Al}_{2} \mathrm{O}_{3}$ (99.995\%, Alfa Aesar), $\mathrm{CaSiO}_{3}$ (99.99\%, Alfa Aesar), $\mathrm{MgO}$ (99.95 \%, Alfa Aesar), and $\mathrm{SiO}_{2}$ (99.99\%, Umicore) were mixed to obtain a near-eutectic 1:1 mixture of anorthite $\left(\mathrm{CaAl}_{2} \mathrm{Si}_{2} \mathrm{O}_{8}\right)$ and diopside $\left(\mathrm{CaMgSi}_{2} \mathrm{O}_{6}\right)$. After firing and homogenization of the powders, 2 grams of the mixture was enriched in Th and $U$ by adding $4 \mathrm{ml}$ of $1000 \mathrm{mg} \cdot \mathrm{L}^{-1} \mathrm{Th}$ in $2 \% \mathrm{HNO}_{3}$ solution, and same quantity and concentration of $\mathrm{U}$ in solution. The charge was welded into a platinum capsule and fused at $1600{ }^{\circ} \mathrm{C}$ for 4 hours in a gas-mixing furnace at ETH Zürich. Composition and homogeneity of the new optimization material was tested by numerous LA-ICP-MS analyses referenced against NIST 610 (Table 2). Gold concentration in the glass is below the detection limit of $0.3 \mu \mathrm{g} \cdot \mathrm{g}^{-1}$. Sulfur is below the detection limit of $305 \mu \mathrm{g} \cdot \mathrm{g}^{-1}$, limited by the $\mathrm{S}$ gas blank level.
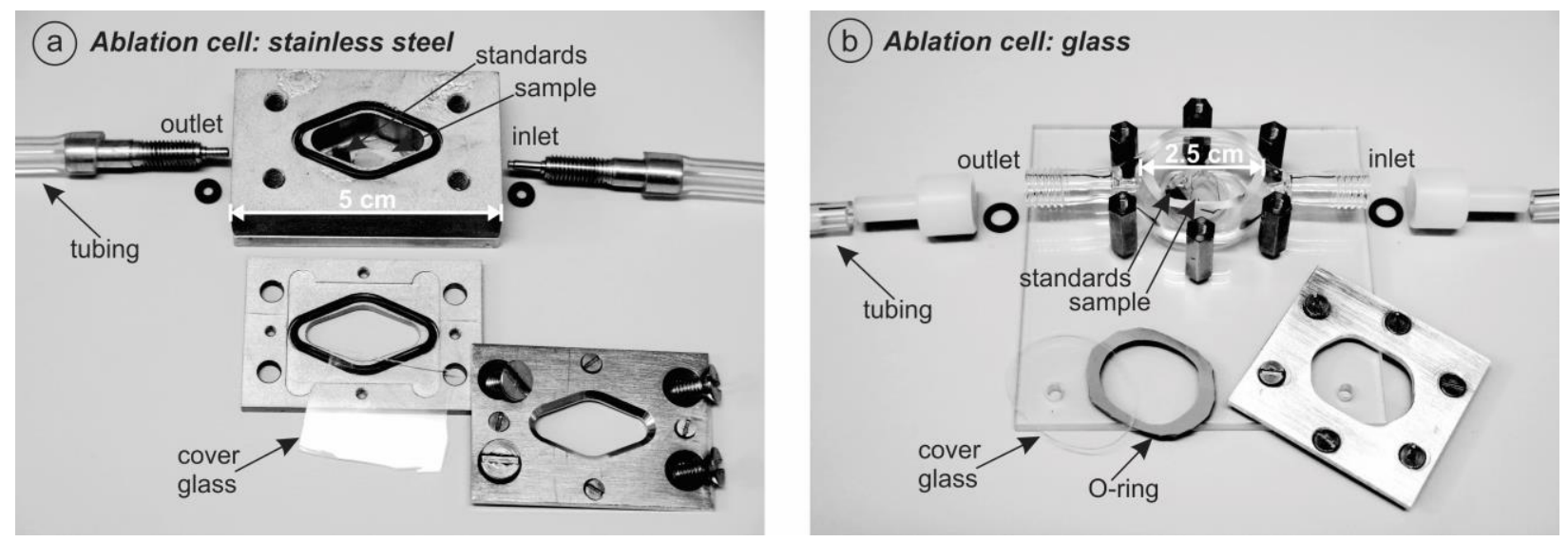

Fig. 1 Design of two alternative dismantled ablation cells: (a) stainless steel, as used in previous studies in our lab; and (b) a new glass ablation cell designed by K. Kouzmanov, initially for work with opaque host materials including complex sulfides.

\subsection{Sample selection}

Fluid inclusions used in our study occur as petrographically well-constrained assemblages of numerous high-salinity (28-39 wt. \% $\mathrm{NaCl}_{\text {eq }}$ ) brine inclusions and low-salinity (1-6 wt. \% $\mathrm{NaCl}_{\text {eq }}$ ),

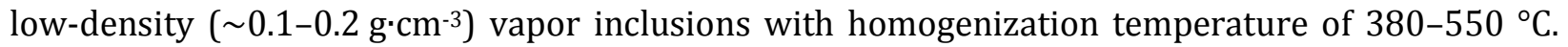
They are hosted in quartz, topaz and beryl from several locations in the Sn-W-mineralized Mole Granite (Eastern Australia) described previously by Audétat and coworkers ${ }^{2,48}$. A test for trace element composition of the host minerals, notably tantalum, was done on quartz- and topaz-hosted brine (32-35 wt. \% $\mathrm{NaCl}_{\text {eq }}$ ) and vapor (5-9 wt. \% $\mathrm{NaCl}_{\mathrm{eq}}$ ) inclusions from Schneckenstein hydrothermal rhyolitic breccia, which is related to the Tannenberg Sn-mineralized topaz-quartz greisen system (Western Erzgebirge, Germany) ${ }^{49,50}$. Additional testing of the ablation properties of topaz was carried out using gemstone quality topaz containing $\mathrm{CO}_{2}$-bearing low-salinity $(\sim 1.6 \mathrm{wt}$. \% $\mathrm{NaCl}_{\text {eq }}$ ) aqueous inclusions on healed microfractures (Dassu, Gilgit Division, Pakistan). The sizes of fluid inclusions in all samples varies from 10 to $120 \mu \mathrm{m}$. The depth and size of all inclusions were measured prior to ablation to estimate the ablation rate of various host minerals and the inclusion volume.

Table 2 Composition and homogeneity of the Th-U-bearing anorthite-diopside glass for ICP-MS optimization. Silica content of the glass used as internal standard $\left(50 \% \mathrm{SiO}_{2}\right.$, based on preparation). Limits of detection (< values) calculated based on 
equation 6 in Pettke et al.18, except for sulfur where the limit is given by the high value of instrumental background and calculated by the procedure of Longerich ${ }^{11}$.

\begin{tabular}{|c|c|c|c|c|}
\hline \multirow[t]{2}{*}{ Element } & \multirow{2}{*}{$\begin{array}{l}\text { Isotope } \\
\text { measured }\end{array}$} & \multicolumn{2}{|c|}{ Concentration $\left[\mu \mathrm{g} \cdot \mathrm{g}^{-1}\right]$} & \multirow[b]{2}{*}{$\operatorname{RSD}[\%]$} \\
\hline & & Mean $(n=22)$ & $2 \mathrm{SD}$ & \\
\hline $\mathrm{Li}$ & 7 & 6.39 & 1.17 & 9.3 \\
\hline $\mathrm{Be}$ & 9 & $<1.12$ & 0.18 & 8.0 \\
\hline B & 11 & $<2.57$ & 0.45 & 9.0 \\
\hline $\mathrm{Na}$ & 23 & 11,914 & 542 & 2.3 \\
\hline $\mathrm{Mg}$ & 24 & 57,468 & 2357 & 2.1 \\
\hline $\mathrm{Al}$ & 27 & 78,033 & 2915 & 1.9 \\
\hline $\mathrm{Si}$ & 29 & 233,733 & & \\
\hline $\mathrm{S}$ & 34 & $<305$ & 102 & 17.1 \\
\hline K & 39 & 449 & 28 & 3.2 \\
\hline $\mathrm{Ca}$ & 44 & 147,375 & 7032 & 2.4 \\
\hline $\mathrm{Ti}$ & 47 & 95.87 & 6.28 & 3.4 \\
\hline $\mathrm{Mn}$ & 55 & 594 & 29 & 3.2 \\
\hline $\mathrm{Fe}$ & 57 & 2,292 & 121 & 2.7 \\
\hline Co & 59 & 0.59 & 0.25 & 21.8 \\
\hline $\mathrm{Ni}$ & 62 & $<18.05$ & 4.02 & 11.4 \\
\hline $\mathrm{Cu}$ & 65 & 29.78 & 1.81 & 3.1 \\
\hline $\mathrm{Zn}$ & 66 & 9.58 & 0.93 & 5.0 \\
\hline $\mathrm{Ga}$ & 69 & 4.83 & 0.49 & 5.2 \\
\hline $\mathrm{Ge}$ & 72 & $<0.87$ & 0.15 & 8.6 \\
\hline As & 75 & $<0.50$ & 0.11 & 10.9 \\
\hline $\mathrm{Rb}$ & 85 & 4.92 & 0.33 & 3.5 \\
\hline $\mathrm{Sr}$ & 88 & 29.65 & 1.74 & 3.0 \\
\hline $\mathrm{Zr}$ & 90 & 8.04 & 0.59 & 3.7 \\
\hline Mo & 95 & 0.56 & 0.18 & 15.9 \\
\hline $\mathrm{Ag}$ & 107 & 0.19 & 0.08 & 21.4 \\
\hline $\mathrm{Cd}$ & 111 & $<0.15$ & 0.07 & 25.9 \\
\hline Sn & 118 & 2.39 & 0.55 & 11.8 \\
\hline $\mathrm{Sb}$ & 121 & $<0.09$ & 0.05 & 29.2 \\
\hline Cs & 133 & $<0.12$ & 0.02 & 10.3 \\
\hline $\mathrm{Ba}$ & 137 & 5.01 & 0.63 & 6.4 \\
\hline $\mathrm{Ta}$ & 181 & 0.03 & 0.01 & 25.3 \\
\hline W & 182 & 52.69 & 2.45 & 2.4 \\
\hline $\mathrm{Au}$ & 197 & $<0.03$ & 0.005 & 9.5 \\
\hline $\mathrm{Pb}$ & 208 & 0.57 & 0.12 & 10.8 \\
\hline $\mathrm{Bi}$ & 209 & $<0.04$ & 0.01 & 11.1 \\
\hline Th & 232 & 3,976 & 233 & 3.0 \\
\hline $\mathrm{U}$ & 238 & 2,738 & 158 & 3.0 \\
\hline
\end{tabular}

\subsection{Interference separation}

Analysis of sulfur and gold in geological samples by ICP-MS comes with the challenge of isotope interferences. ${ }^{26,51}$ Naturally abundant sulfur isotopes are ${ }^{32} \mathrm{~S}\left(95.02 \%\right.$ abundance) and ${ }^{34} \mathrm{~S}(4.21 \%$ abundance), which both suffer from polyatomic interference from ${ }^{16} \mathrm{O}^{16} \mathrm{O}^{+}$and ${ }^{16} \mathrm{O}^{18} \mathrm{O}^{+}$, respectively resulting from oxygen in ambient air. ${ }^{26}$ However, in medium mass resolution, the interferences of $\mathrm{O}^{2+}$ and $\mathrm{S}^{+}$species can be resolved, as described by Guillong et al. ${ }^{26}$. 
Although gold occurs in nature as a single isotope of ${ }^{197} \mathrm{Au}$, mass 197 also hosts a refractory oxide of tantalum $\left({ }^{181} \mathrm{Ta}^{16} \mathrm{O}^{+}\right) .{ }^{52}$ To evaluate this potential interference, quartz samples were analyzed for ${ }^{181} \mathrm{Ta}$ and were found to contain no detectable Ta. Topaz and beryl can contain a trace amount of Ta (up to a few $\mu \mathrm{g} \cdot \mathrm{g}^{-1}$ ) depending on the actual sample and locality. However, since Ta is only present in the host and not in the inclusion itself, it appears like an elevated Au content in the host and is corrected for by subtraction of the host matrix. This host correction affects the LOD, however. In order to keep the LOD as low as possible, the oxide formation rate was further reduced $(<0.01 \%)$ while measuring those samples to minimize the $\mathrm{TaO}^{+}$effect in the host correction.

\section{Sources of contamination and recommended elimination procedures}

We observe three types of contamination remaining after recognition and possible elimination of isobaric mass interferences. The first source of contamination expresses itself in high background count rates during continuous gas flow to the ICP-MS. The second is related to deposition and remobilization of contaminants in the analyte transport system of the LA-ICP-MS. It makes the appearance as if the contaminant was contained in the host mineral, because of a signal elevation during ablation of a host mineral even if it is demonstrably free of the concerned contaminant. The third is direct contamination on the ablated sample surface, which commonly cannot be removed by simple polishing or solution cleaning and may lead to ambiguous results with inclusions situated close to the surface (Fig. 2a).

\subsection{Continuous background contamination}

Gas blank levels are a limiting factor for determining of gold and sulfur in diluted fluids. Their analysis by ICP-MS is problematic due to a high background intensity coming from contamination of the instrument, ambient air and other sources. ${ }^{21,26,27}$ We highlight two sources of increased background intensity for both S and Au and other important elements: (1) the quality of the carrier gas; and (2) the deposition of previously ablated material on the skimmer and sampler cone at the entrance to the mass spectrometer, which may accumulate to a longer-term memory effect.

Impurities in the carrier gas transporting the sample aerosol from the ablation cell to the plasma of the ICP-MS are one important source of continuous background contamination. The carrier gas is typically helium, occasionally with minor additions of other gases, such as $\mathrm{H}_{2}$ used for sensitivity enhancement at the Q-ICP-MS ${ }^{53}$. Helium gas can be purchased in variable quality, however, widely used grade is the 5.0 grade $\mathrm{He}$ ( $\geq 99.999 \% \mathrm{He} ; 10 \mu \mathrm{g} \cdot \mathrm{g}^{-1} \mathrm{sum}$ of impurities). Higher purity He, such as 6.0 grade ( $\geq 99.9999 \% \mathrm{He} ; 1 \mu \mathrm{g} \cdot \mathrm{g}^{-1}$ of impurities) and 7.0 grade $\left(\geq 99.99999 \% \mathrm{He} ; 100 \mathrm{ng}^{-1} \mathrm{~g}^{-1} \mathrm{of}\right.$ impurities) is also available, and traditionally used in the semiconductor industry. Grade 6.0 He costs about twice the price of 5.0 quality gas, while the 7.0 He grade is not commonly distributed. The He gas is produced by fractional distillation from natural gas and still contains traces of hydrocarbons, $\mathrm{O}_{2}, \mathrm{H}_{2}, \mathrm{~N}_{2}, \mathrm{H}_{2} \mathrm{O}, \mathrm{CO}, \mathrm{CO}_{2}, \mathrm{H}_{2} \mathrm{~S}$, and other contaminants, such as Ar, $\mathrm{Ne}$, and Hg. ${ }^{54}$ Additional He gas purification methods include cryogenic separation of the hydrocarbons, dehydration, mercury removal and an acid gas removal during which the sulfur compounds are extracted by chemical solvents. ${ }^{54}$ After desulfurization, He gas is claimed to contain less than $1 \mathrm{ng} \cdot \mathrm{g}^{-1}$ total $\mathrm{S}$ (PanGas, Switzerland, personal communication). However, the true $\mathrm{S}$ concentration of the gas cylinder is not analyzed and reported by any of the manufacturers. Refilling by the distributors involves evacuation of the remnants of the old gas before the refilling of a new batch. This procedure might not always be followed. We have observed up to a two-fold difference in $S$ background in various batches of the 5.0 
grade He gas from the same distributor (see Fig. 3). The 6.0 grade He showed more consistently lower $S$ background values, but some of the 5.0 He gas cylinders reached comparable quality. Representative sulfur background for both grades reaches $2 \cdot 10^{5}$ to $10^{6}$ counts per liter He gas estimated to equate to approximately 10 to $50 \mathrm{ng} \cdot \mathrm{g}-1$.
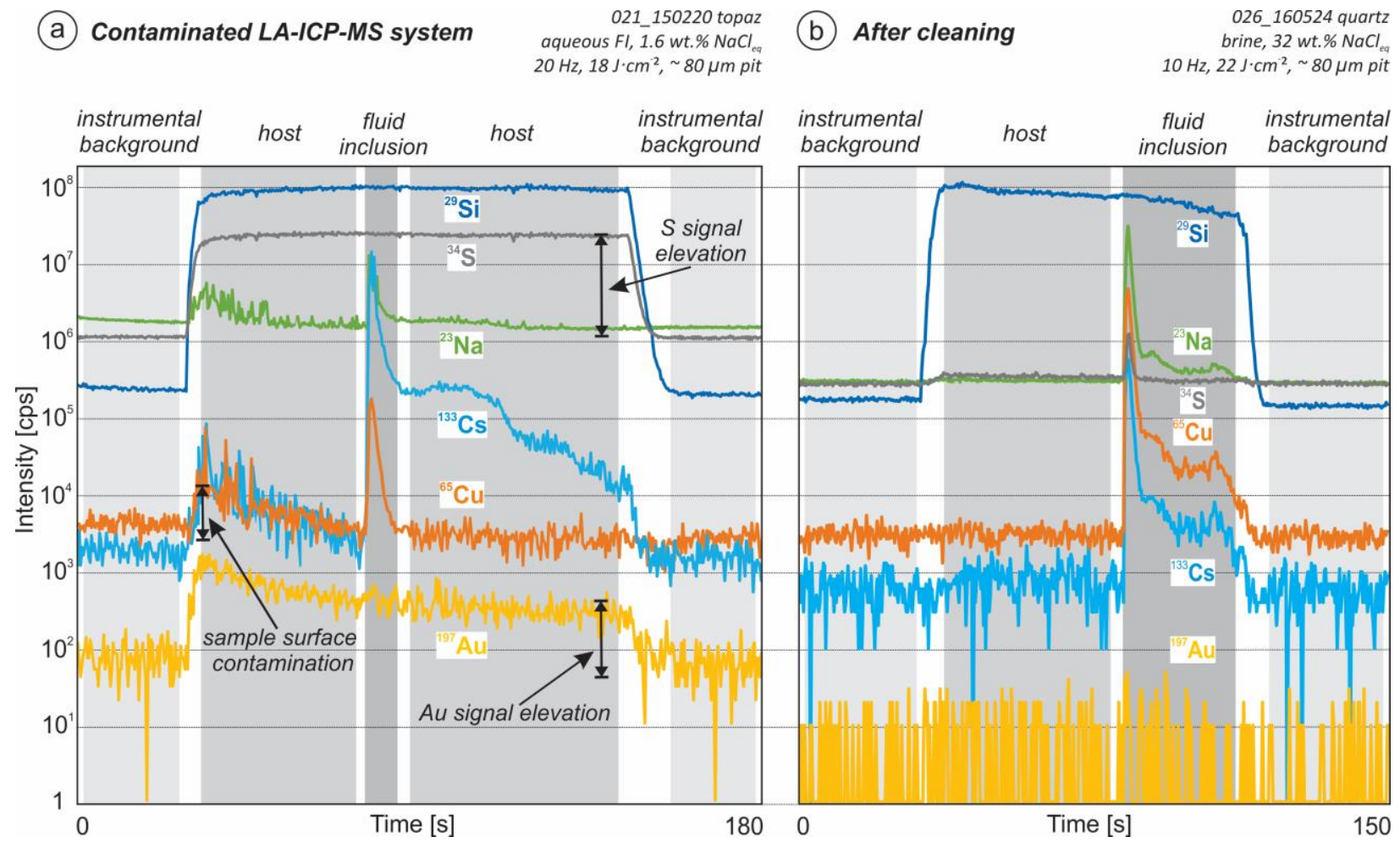

Fig. 2 Transient LA-ICP-MS signals of two $70 \mu \mathrm{m}$-large fluid inclusions showing diverse sources of contaminations (a, left) that were subsequently eliminated step by step to obtain a clean signal (b, right). Analytical conditions: (a) 5.0 grade He, previously used steel ablation cell, polyamide tubing, and un-treated Ni sample cones. Sample polished using diamond paste and exposing debris of material from previously ablated fluid inclusion. (b) 6.0 grade He gas, aqua regia- and alumina suspension-cleaned glass ablation cell, HF-cleaned sample cones, sample surface cleaned by aqua regia and alumina suspension, and pre-ablation of surface debris with ca. $90 \mu \mathrm{m}$ size pit. Signals normalized to same sensitivity based on Si intensity in the NIST SRM 610. Different shades of grey bars distinguish between different parts of the signal: instrumental background, host matrix, and the inclusion. Sample (a) is aqueous inclusion hosted in topaz from Dassu Gilgit, Pakistan; sample (b) is brine inclusion in quartz from Mole Granite, Australia. The detection limits for Au are (a) $0.180 \mu \mathrm{g} \cdot \mathrm{g}^{-1} \mathrm{and}(\mathrm{b})$ $0.003 \mu \mathrm{g} \cdot \mathrm{g}^{-1}$. 


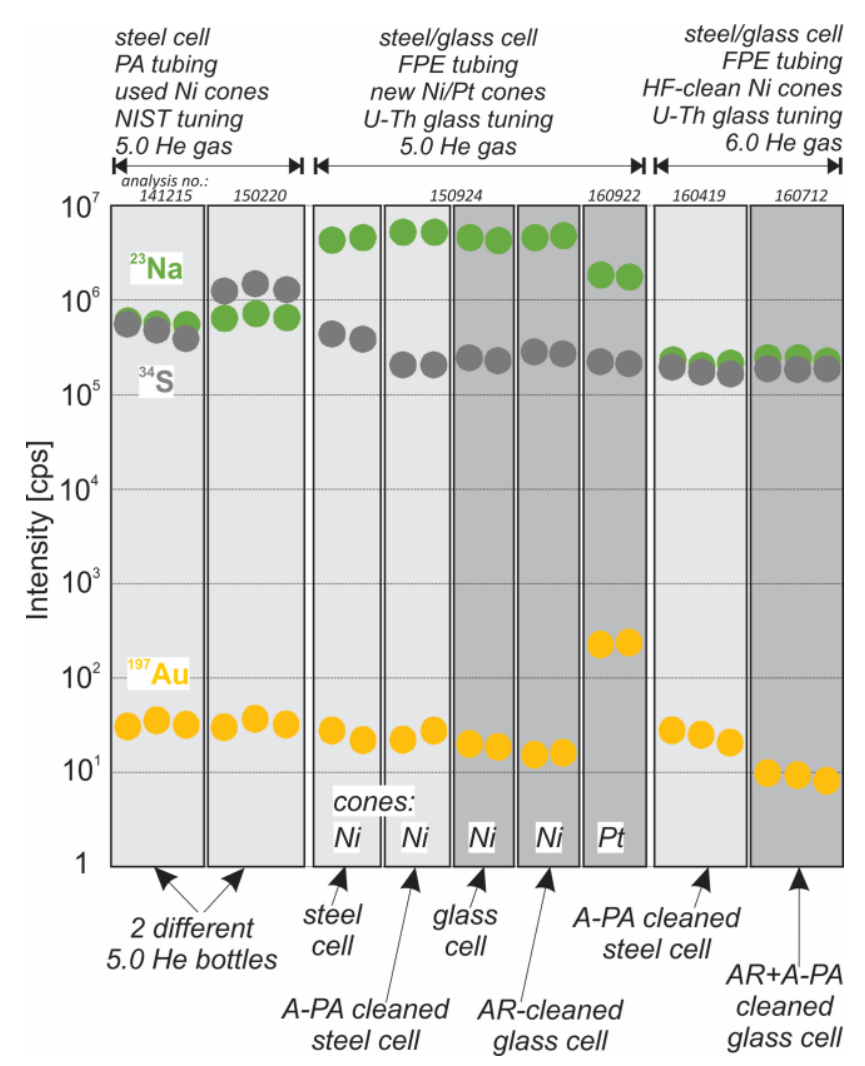

Fig. 3 Successive improvement in instrumental background values of $\mathrm{Na}, \mathrm{S}$, and $\mathrm{Au}$ as a result of different component materials and their cleanliness: ablation cell material (steel = highlighted by light grey background, glass = dark grey background), cleanliness ( $\mathrm{AR}=$ aqua regia cleaning, $\mathrm{A}-\mathrm{PA}=$ alumina polishing suspension), tubing material ( $\mathrm{PA}=$ polyamide, $\mathrm{FEP}$ = fluorinated ethylene propylene), optimization material (NIST 610 or the new U-Th glass material), gas quality (5.0 or 6.0 grade $\mathrm{He}$ ), and sample cones condition (used, new, or HF-cleaned) and material (Ni vs. Pt). All values are extracted from instrumental background during ablation of NIST SRM 610, and normalized to the same intensity of Na on NIST SRM 610 of $3 \cdot 10^{8} \mathrm{cps}$ obtained by ablation with a $40 \mu \mathrm{m}$ pit at $10 \mathrm{~Hz}$ pulse frequency with a laser intensity $\mathrm{of} 12 \mathrm{~J} \cdot \mathrm{cm}^{-2}$.

Additional scrubbing of the He gas was attempted, specifically to reduce backgrounds on ${ }^{32} \mathrm{~S}$ and other gas species in the gas blank. A commercial gas filter for oxygen, which supposedly removes also sulfur compounds (GasClean Filter, Varian), did not have any measureable effect on sulfur. A simple cold trap made by immersing a coil of the helium carrier gas line in liquid nitrogen did not lead to a noticeable decrease in the $S$ background. However, later warming-up of the cold trap after 20 to 30 min of operation back to room temperature resulted in peaks on hydrogen, carbon, oxygen, sulfur, and probably chlorine, including their interferences on masses 54,56 , etc. The relative time delay of the peaks in those different masses indicates that some water with minor other volatiles had condensed in the cold trap. Some of the transient peaks on masses 1, 17, 32 and 56 can be attributed to $\mathrm{H}$ or $\mathrm{O}$ interference. There is also an early peak on masses 13,32 , and 34 but not on 17 and 1 , indicating the presence of some sulfur and carbon species in the system. These results demonstrate that further experiments using cool traps with enlarged exchange surfaces (e.g. activated carbon, zeolites) are worth pursuing.

Helium carrier gas is mixed with argon downstream from the ablation cell, immediately before the entrance to the ICP-MS. Argon gas is supplied as 6.0 grade liquid to a central pressurized tank serving all our ICP-MS labs, from which it is conveyed around the university building. Argon gas can also contain trace amounts of sulfur and might add to the contamination effects. However, the distribution 
system is thought to act as an additional cleaning step because molecules heavier than $\operatorname{Ar}$ (39.948 $\left.\mathrm{g} \cdot \mathrm{mol}^{-1}\right)$, e.g. $\mathrm{SO}_{2}\left(64.066 \mathrm{~g} \cdot \mathrm{mol}^{-1}\right)$, are preferentially retained at the bottom of the liquid Argon tank.

Skimmer and sampler cones are a potential source of long-term memory effect and near-constant background contamination. The cones should be regularly cleaned, as suggested by the manufacturers, to remove deposits of previously ablated material. Careful mechanical scrubbing of the cones by alumina polishing suspension (1 $\mu \mathrm{m}$ AP-A agglomerate alpha alumina, Struers, Denmark) using pointy cotton swabs, a nitric acid bath, followed by an ultrasonic bath with a detergent (Citranox), helps in partially removing the top layers of the deposition. Complete removal can be achieved with hydrofluoric acid, which removes deposits that are derived from ablation of silicates and quartz forming hard crusts on the outside as well as inside edge of the sampler cone. A successful procedure involves heating of the cone on a hot plate, immersing it in an ultrasonic bath of concentrated HF, followed by a thorough ultrasonic rinse with distilled water to ensure removal of any acid residues. Our experience shows that HF-cleaned skimmer and sampler cones lead to background intensities for $\mathrm{Au}, \mathrm{S}, \mathrm{Na}$, and other elements at even lower values than freshly purchased cones (see Fig. 3). Even if HF cleaning might decrease the lifetime of the cones, it is safer than mechanical scrubbing, which may alter the precise and delicate shape of the cone. Platinum cones are found to be more resistant and easier to clean than nickel cones, but clean Pt cones yield higher background intensities of gold (tens to hundreds of cps), compared to cleaned Ni cones (up to $20 \mathrm{cps}$ for the same sensitivity; see Fig. 3). This is probably due to a trace amount of gold in the platinum cone material. Cones made of aluminum show lower count rates on the desired elements and are more sensitive to mechanical and chemical cleaning, hence, these cones were not used during the experiments.

\subsection{Contamination mobilized from the analyte transport system}

Guillong and coworkers ${ }^{21,26}$ were the first to discover an effect of contamination that is mobilized by the UV laser, giving the false appearance of a minor element within the solid analyte. This source of contamination causes elevation of the sulfur signal (tens to hundreds of $\mu \mathrm{g}^{-g^{-1}}$ apparent $\mathrm{S}$ concentration) during ablation of a sulfur-free host mineral (e.g. quartz, topaz) or material (opticalgrade fused silica ${ }^{26}$ ) and thus, limits the successful quantification of sulfur content of fluid inclusions ${ }^{21,26}$. A similar effect of an elevated signal during ablation of a host, free of the concerned element, has been observed for $\mathrm{Au}$ (a few to tens of $\mathrm{ng}^{\mathrm{g}} \mathrm{g}^{-1}$ apparent Au concentration even after ruling out ${ }^{181} \mathrm{Ta}^{16} \mathrm{O}^{+}$interference on ${ }^{197} \mathrm{Au}$ ), as well as for $\mathrm{Cl}$ and $\mathrm{Br}^{8,21}, \mathrm{Sn}$, and $\mathrm{Hg}$. The elevated element signal follows the pattern of the host mineral ablation (e.g. follows the signal of Si in quartz or silicate glass) even if the substance contains none of these impurities (e.g. optical-grade fused silica).

A scenario for an ordinary every-day set-up for the analysis of $\mathrm{Au}$ and $\mathrm{S}$ in fluid inclusions is illustrated in Fig. 2a, which was initially dominated by several sources of contamination. Under these conditions, any small Au or S peak from a fluid inclusion would be completely overlapped by the falsely elevated Au and S signals (up to an order of magnitude false elevation for both elements). Our tests showed that the contamination originates from two sources along the analyte transport system: (1) the ablation cell; and (2) the connection tubing between the cell and the ICP-MS. Fig. 2b demonstrates a successful fluid inclusion analysis using the same analytical set-up after the cleaning procedures described in the following sections.

Ablation cell material and its cleanliness was tested with three different custom-made ablation cells to determine how different materials contribute to contamination and how the interior cell surfaces can be cleaned. In general, ablation cells should be designed to have a minimum number of corners 
and no-flow regions (including connectors) where unstable accumulations of ablated material can be deposited and subsequently released to the gas stream ${ }^{42,55}$. Two in-house built rhomb-shaped ablation cells of $\sim 1 \mathrm{~cm}^{3}$ volume (a) that are easy to handle were made from aluminum alloy and stainless steel. Chemical cleaning of the aluminum alloy and stainless steel (a) can be achieved with a metal cleaning detergent and concentrated nitric acid ${ }^{21}$ and/or mechanical scrubbing by A-PA alumina polishing suspension. This helps reducing the false sulfur signal effect, but does not significantly improve the elevated gold signal irrespective of the cell metal. Moreover, acid cleaning corrodes these cells to a porous surface. Both the stainless steel and the alumina cells induce elevated Sn signal (up to $100 \mathrm{ppm} \mathrm{Sn}$ ) during ablation of Sn-free material, probably by retaining Sn particles from previous analytical session when Sn-bearing material was ablated and implanted into the porous metal surface. The Sn elevation is not reduced by cleaning with acids and polishing with the A-PA alumina suspension. A round glass cell of $\sim 1 \mathrm{~cm}^{3}$ of volume, (b) was made by a glass-blower as a single piece of quartz glass. A planar rim was ground on the top, barely exposing a $1 \mathrm{~mm}$ thin Teflon ring sealing the optical-grade glass window (coated for maximum 193-nm photon transmission) pressed onto the seal by a metal frame and six screws. This window is difficult to handle and prone to leaking or breaking. However, the glass cell can be cleaned rigorously by immersion in an ultrasonic bath containing aqua regia $\left(\mathrm{HNO}_{3}+\mathrm{HCl}, 1: 3\right)$ to dissolve any gold and other metal residues, followed by ultrasonic cleaning in distilled water. After chemical cleaning, a laser-induced S elevation still persists. This is possibly because nitric acid is concentrated by an Ostwald process using $\mathrm{H}_{2} \mathrm{SO}_{4}{ }^{56}$ leaving traces of $\mathrm{S}$. This is removed with a second step of mechanical cleaning by ultrasonic agitation of the glass cell in a thick slurry of fine epoxy beads (as used for warm-pressed epoxy mounts) mixed with the AP-A alumina polishing suspension, followed by several cycles of ultrasonic rinsing in distilled water.

Other sulfur-bearing materials, such as an 0-ring inside the ablation chamber and at the outlets, either grains or particles of sulfide minerals present in the sample, can contribute to the elevation of the S signal21. Thus, direct contact of the carrier gas and the ablated particle stream with these contamination sources should be minimized or avoided.

Transport tubing coupling the ablation cell and the ICP-MS may also contain a significant amount of contaminants or be a source of memory effects. Various types of tubing materials are routinely used in ICP-MS laboratories: polyamide (PA), PVC, Tygon (C), FEP, or Teflon (C (PTFE). We observed a strong increase in the sulfur signal when using a polyamide tubing (Legris, France). Ablation of the actual tubing showed a significant sulfur content and other elements, such as Zn (Fig. 4a). However, the rapid decrease of the signal while ablating the tubing and the lack of a suitable standard does not allow quantifying the true content of the contaminants. We found that PVC (Nalgene ${ }^{\mathrm{TM}}$, USA) and Tygon (C) (Saint-Gobain, UK) are S-free but contain traces of B, K, Zn, As, Sb, and Ba (Fig. 4b). The PTFE and FEP (Rotilabo®, Carl Roth $\mathrm{GmbH}$, Germany) are free of all these components although PTFE might contain minor $\mathrm{Cu}$ and $\mathrm{Pb}$ (Fig. 4c). 


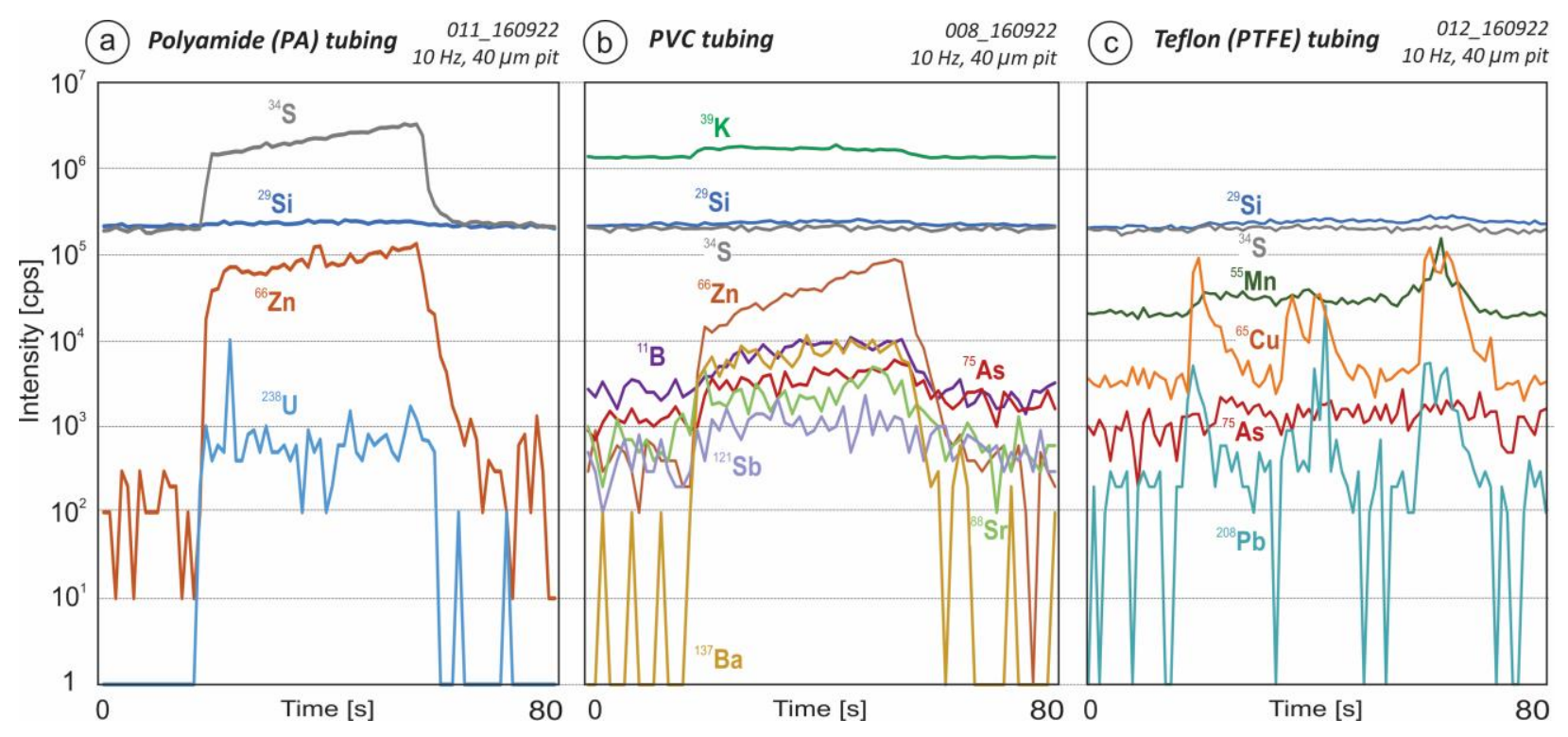

Fig. 4 Transient LA-ICP-MS signals of selected trace elements contained in three materials that are typically used for connection tubing: (a) PA, (b) PVC, (c) PTFE, where three signal spikes denote three successive ablation spots where the material does not ablate in a stable manner. FEP tubing does not produce any ablation signal.

The mechanism of laser-induced memory effects of elevated element signals seem to be different for metals and for sulfur, i.e., there are two sources of contamination in the transport system that react differently to the laser. The gold and also tin signals only rise when the laser is focused on the sample surface but occurs even if an entirely pure material is physically ablated. These elevations are probably caused by mechanical effect of the sample aerosol, abrading the walls of the cell and possibly mobilizing material deposited from previous ablation shots along the analyte transport line. The elevation of the tin signal results from abrasion of the walls of the metallic ablation cells. Generally, the greater the ablation rate and the diameter of the ablation pit, the higher is the mass of the sample aerosol and therefore, the higher is the laser-induced abrasion effect. With the Scontaining polyamide tubing, mechanical abrasion of the tubing also dominates the elevated sulfur signal (as shown in Fig. 2a). However, the sulfur signal may rise even with S-free tubing and when a defocused laser beam is fired into the ablation cell without physically ablating any material. This elevated sulfur signal is likely caused by photochemical desorption from the interior surfaces of the sample chamber resulting from the laser light ${ }^{21}$. Currently, it is not possible to completely eliminate S contamination ( $\sim 10000-100000 \mathrm{cps}^{34}$ S, background corrected), but a careful host correction can be applied for correct $S$ quantification ${ }^{26}$.

In conclusion, an all-glass cell that is regularly cleaned by aqua regia and alumina polishing suspension is recommended for fluid inclusion analysis, together with a trace element-free tubing material like FEP or PTFE, even though it is stiffer and less convenient to handle. In addition, regular blank ablations on a trace element-free material (e.g. optical-grade fused silica) are needed to document whether any trace element elevations following the host mineral signal are indeed part of the host mineral, or whether they are due to laser-induced liberation of contaminants from the transport system, which can be minimized by further cleaning. In any case, careful subtraction of the host ablation baseline bracketing the transient inclusion signal is essential to quantify element peaks attributed to the inclusion contents. This requires that the surface of the host mineral is free of any local contamination, a challenge which we discuss next. 


\subsection{Sample surface contamination}

There are two types of surface contamination. The first can result from sample preparation and can be minimized before the sample is loaded into the ablation cell. Polishing agents and equipment can introduce $\mathrm{Au}$ and other elements, such as $\mathrm{Cu}$ and $\mathrm{Ce}$, during sample preparation and thus contaminate the sample surface. ${ }^{55}$ Subsequent abrasive polishing with diamond paste remobilizes the contaminants on the surface but may not completely remove them, and some polishing products contain significant amounts of $\mathrm{Au}$ and $\mathrm{Cu}$. Gold contamination in the top nanometers of polished quartz cannot be completely removed by aqua regia and requires re-polishing with A-PA alumina suspension, which appears to be free of any contaminants. ${ }^{55}$ Provided that the host material can withstand it, the following cleaning procedure for small inclusion chips, after their petrographic mapping, has shown to be the most successful: (1) remove all metallic minerals by aqua regia; (2) repolish with A-PA alumina suspension by finger on firm cloth, clean glass plate or paper for a few minutes; (3) a second aqua regia wash, followed by (4) ultrasonic rinse with distilled water (not recommended for cleavable minerals such as topaz). Finally, chips can be fixed onto a clean glass carrier inside the ablation cell using blu-tack (Bostik, France), avoiding any glue on the back side of the chip as it decomposes during ablation, impairing visibility and potentially liberating volatile contaminants.

Deposition of material from previous ablations is the second source of surface contamination that can hinder meaningful inclusion analysis. ${ }^{16,18}$ Surface contamination is especially profound for minerals with a low ablation rate, such as topaz, where an extended duration of the signal is more likely to overlap with a short inclusion signal, especially from inclusions situated close to the sample surface (Fig. 2a). In contrast to quartz, which is commonly ablated by a repetition rate of $10 \mathrm{~Hz}$, we use $20 \mathrm{~Hz}$ for topaz and beryl, which both have approximately two times slower ablation rate. Faster ablation improves signal to background ratios and LOD 16 . The first measure to reduce surface contamination is the use of our new glass material for tuning at the start of a session. The other step is to clean all debris resulting from previous ablation of neighboring inclusions. ${ }^{16}$ We target inclusions at a depth between one and two inclusion diameters below surface, so they are not breached shortly after the initiation of the ablation ${ }^{18}$ but are not yet affected by down-hole element fractionation that becomes significant from 3 pit diameters or deeper ${ }^{57}$. The suggested stepwise preablation cleaning procedure is illustrated in Fig. 5. The same laser energy and repetition rate as used for the inclusion analysis is employed, but with a wider ablation pit than the final diameter needed for complete excavation of the actual inclusion. Cleaning shots are continued until all debris and redeposited material have been removed, the sample surface is visibly clean, and no residual counts of contaminants are obtained. During cleaning of the host surface by laser shots, the mass-spectrometer records all elements of interest to monitor the cleaning progress (Fig. 5). The inclusion is then analyzed with a slightly narrower pit size, after the laser has been refocused on the new sample surface. This cleaning method is suitable for minerals that ablate well, such as topaz, beryl, carbonates, halite, garnet and other silicates. Some quartz grains tend to crack during surface cleaning or analysis, potentially resulting in explosive opening of the inclusion, which prevents subsequent signal quantification. This is more prevalent in samples that have larger amount of cracks or dense populations of inclusions. We have observed that quartz samples covered by thick ablation debris, typically in close vicinity to the previous ablation pits, are less prone to cracking and explosion. Further tests with clean coatings are in progress to possibly exploit this positive effect. 
(a) Stepwise pre-ablation cleaning procedure
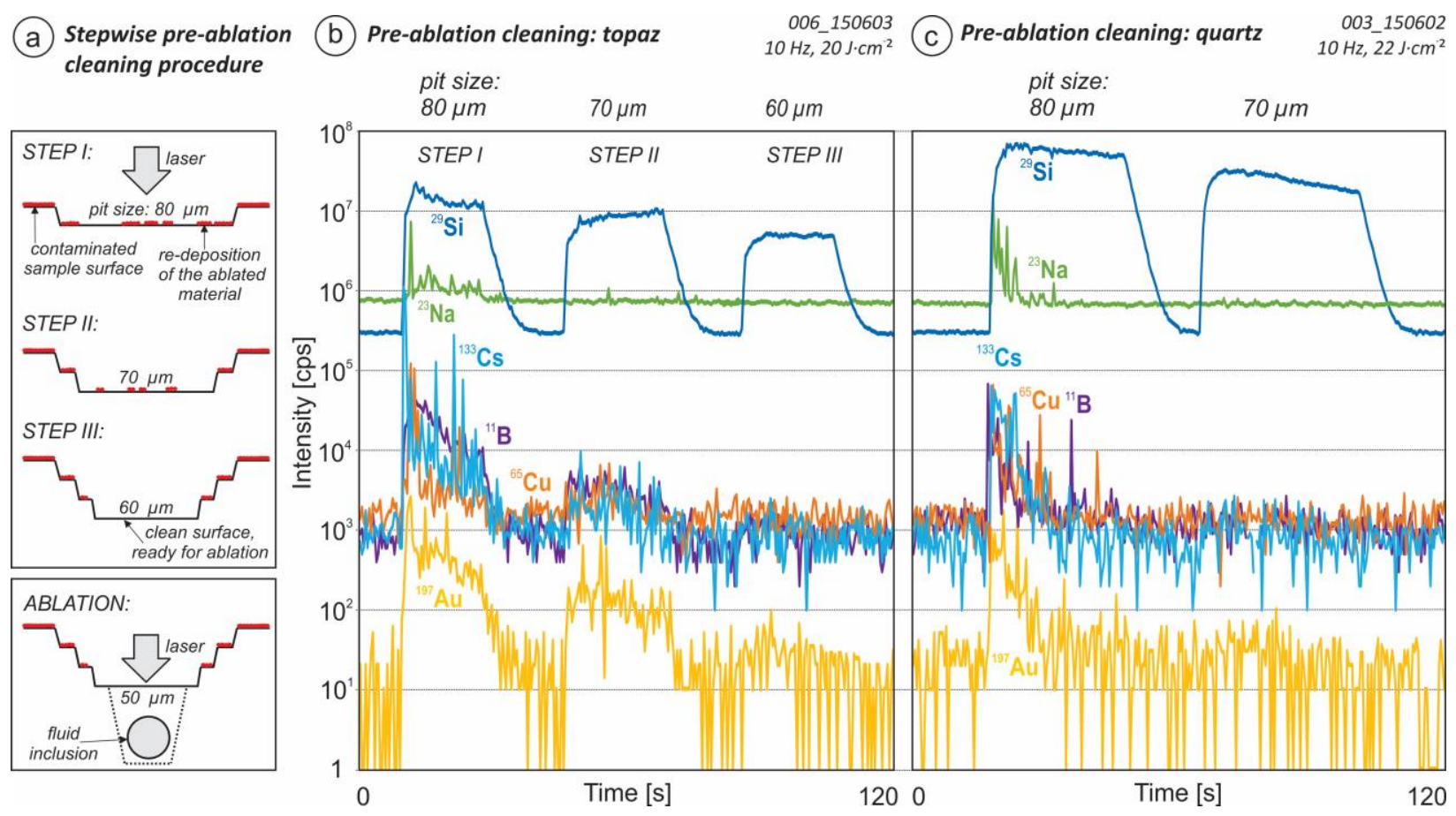

Fig. 5 (a) Stepwise pre-ablation procedure for cleaning of the aerosol debris (illustrated in red) resulting from ablation of previous/neighboring inclusions. Transient LA-ICP-MS signals monitoring the progress of the pre-ablation cleaning: (b) topaz, (c) quartz. Samples from Mole Granite, Australia. See text for details.

\section{Limits of detection}

The absolute detection limit, in grams of an element present in a single fluid inclusion, is a function of instrument sensitivity and background noise for each element ${ }^{17}$, but it primarily depends on the total mass (i.e. size) of the inclusion. In addition, the detection limit is influenced by the opening procedure determining the total length of a signal and hence, the signal-to-background ratio. This, in turn is affected by ablation rate and inclusion depth, and also by the number of elements recorded during sequential analysis in sector-field or quadrupole mass spectrometers ${ }^{18,20}$. Rigorous assessment of the precision of paleo-fluid compositions requires analysis of multiple inclusions in an assemblage of coeval inclusions thought to be iso-compositional based on petrographic criteria, but the calculation of maximum possible concentration of an element, i.e., the detection limit in $\mathrm{Ig}^{-\mathrm{g}^{-1}} \mathrm{of}^{\mathrm{f}}$ fluid, is far from trivial.

In this study, we use inclusions between 10 and $120 \mu \mathrm{m}$ in size to explore different ways of estimating detection limits in average fluid concentrations. For absolute element detection in single highly saline brine inclusions, the ideal size proved to be 20-50 $\mu \mathrm{m}$. Larger inclusions produce long and spreadout signals, especially in the case of slowly ablating topaz, and no further improvement in the signal/background ratio. High-density brines contain higher amounts of most analytes and at the given ablation rate of the particular mineral, they typically return lower absolute detection limits. Vapor-dominated inclusions contain lower amounts of analyte and therefore, the bigger the inclusions, the better the chance of detecting desired trace elements present in sub $\mu \mathrm{g} \cdot \mathrm{g} \cdot{ }^{-1}$ quantities ${ }^{20}$. Low-density $\left(\sim 0.1 \mathrm{~g}^{\cdot} \mathrm{cm}^{-3}\right)$ vapor inclusions of $50-80 \mu \mathrm{m}$ in size proved to be the most feasible for this purpose, while vapor inclusions smaller than ca. $20 \mu \mathrm{m}$ did not yield any sulfur and/or gold signal. For very large inclusions $(>100 \mu \mathrm{m})$ or inclusions with more complex topology (e.g. elongate or irregular shapes), there is a risk of incomplete and non-representative sampling. 
Absolute limits of detection in individual inclusions were calculated based on criteria by Pettke et al. ${ }^{18}$, considering that low count rates require Poisson statistics. For example, using only a short menu

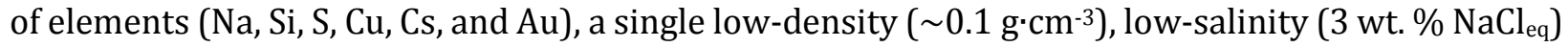
vapor inclusion of $70 \times 70 \mu \mathrm{m}$ at ca. $150 \mu \mathrm{m}$ depth in quartz yields an absolute detection limit for gold of $10^{-17} \mathrm{~g}$ (i.e. $\sim 30,000 \mathrm{Au}$ atoms) and $10^{-13} \mathrm{~g}$ for sulfur ( 200,000 $\mathrm{S}$ atoms). Thus, detection limits for trace element concentrations in individual inclusions depend primarily on the count rate of the internal standard used for absolute quantification (i.e. the height of the Na signal) in most fluid inclusion applications.

A representative composition of a geological fluid is assured by analysis of numerous fluid inclusions in a petrographically well-defined assemblage. Arithmetic averages of the concentrations and the standard deviations of individual analyses are calculated and usually reported as representative estimates of the fluid composition. ${ }^{16}$ However, reporting the geometric mean has the advantage of giving less weight to the largest concentration values and moreover, allows calculation of uncertainties that do not extend to negative concentration values. ${ }^{55}$ This is appropriate for elements that are well above their detection limit. In the case of gold - an example of a low-concentration fluid constituent - randomly detected, high but scattered gold values dominate the calculated average and lead to an overestimation of the true concentration of the fluid inclusion population. ${ }^{38}$ Such a bias can be eliminated by summing the signals of all inclusions in an assemblage. ${ }^{35}$ The summation method improves the limit of detection and brings more accurate values for elements close to their detection limit. It effectively weights the results by the quality of the overall LA-ICP-MS signal that is measured by the total counts on $\mathrm{Na}$, used as internal standard. Calculations using statistical methods for censored data described in Helsel ${ }^{58}$ applied to the individual concentration data results in similar values to the average and the geometric mean of detected values for the fluid inclusion assemblage (Table 3). The Kaplan-Meier (K-M), regression on order statistics (ROS), and maximum likelihood estimation (MLE) Au values are 0.11, 0.10, and $0.81 \mu \mathrm{g} \cdot \mathrm{g}^{-1}$, respectively, while the average and the geometric mean values are 0.65 and $0.08 \mu \mathrm{g} \cdot \mathrm{g}^{-1}$, respectively. The summation method returns mean concentration of $0.004 \mu \mathrm{g} \cdot \mathrm{g}^{-1} \mathrm{Au}$ (Table 3). Fig. 6 illustrates a single vapor inclusion signal vs. summed signals of 44 vapor inclusions in an assemblage, and the difference between calculated mean element concentrations and their summary statistics estimate (K-M or ROS methods) compared to the values returned by the summation method. The $\mathrm{Cu}, \mathrm{S}$, and $\mathrm{Cs}$ average concentration values coincide with the summed values, while the $\mathrm{Au}$ concentration derived from the censored data summary statistics is significantly overestimated and dominated by the few successful, relatively high $\mathrm{Au}$ analyses. This example of Au shows that the summary statistic methods described by Helsel ${ }^{58}$ have their limitations when estimating representative averages if there is a high scatter and a high rate of non-detects in the dataset (e.g. $84 \%$ non-detects in the presented example). We therefore recommend the summation method which is more robust in those situations. The summation was done with a new Matlab script in SILLS 44 that sums all background, matrix, and fluid inclusion intervals, individually pre-selected in SILLS for all single inclusions in an assemblage. 
(a) Single fluid inclusion signal

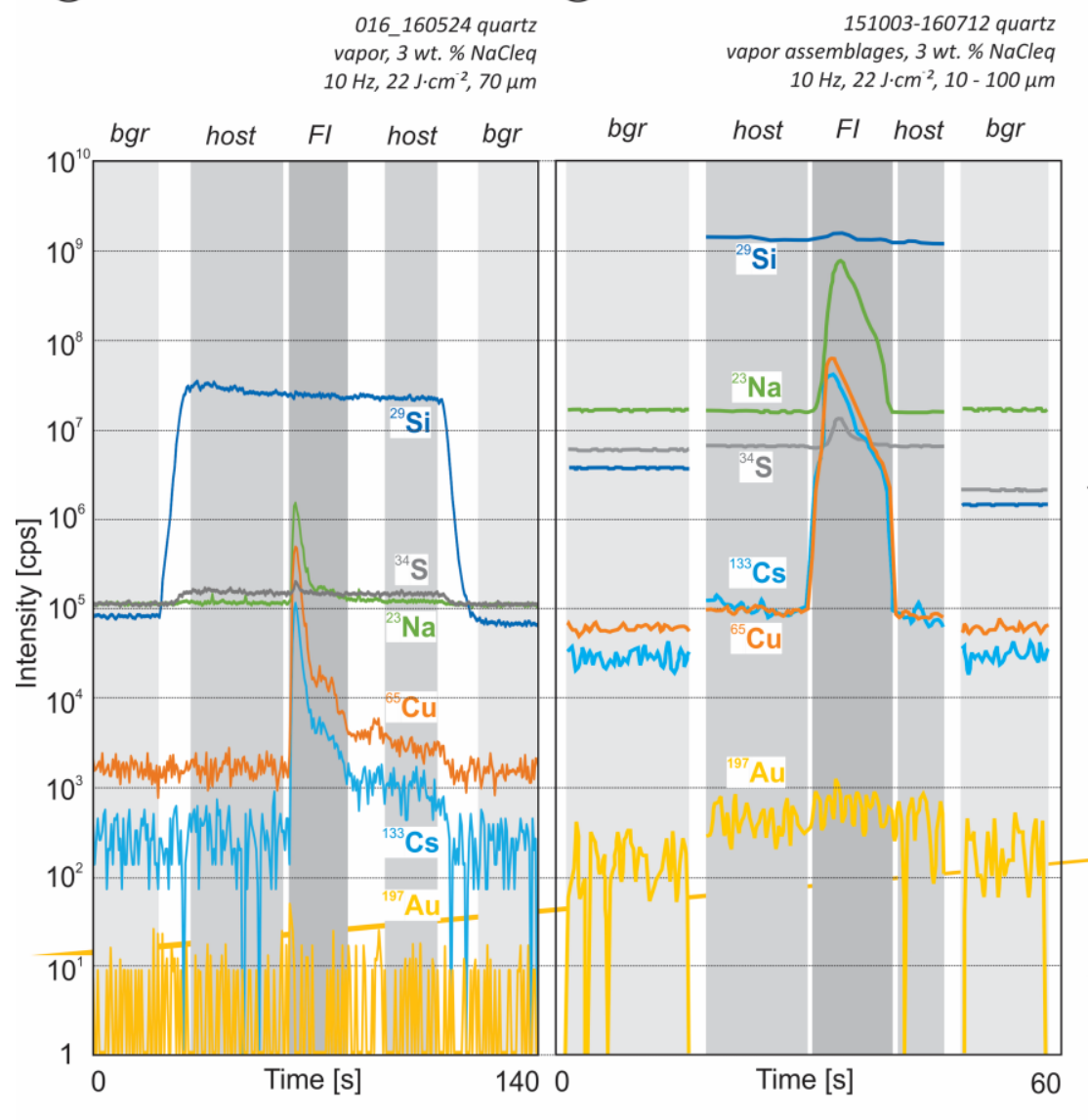

(C) Concentration and LOD for 44 single inclusions vs. summation

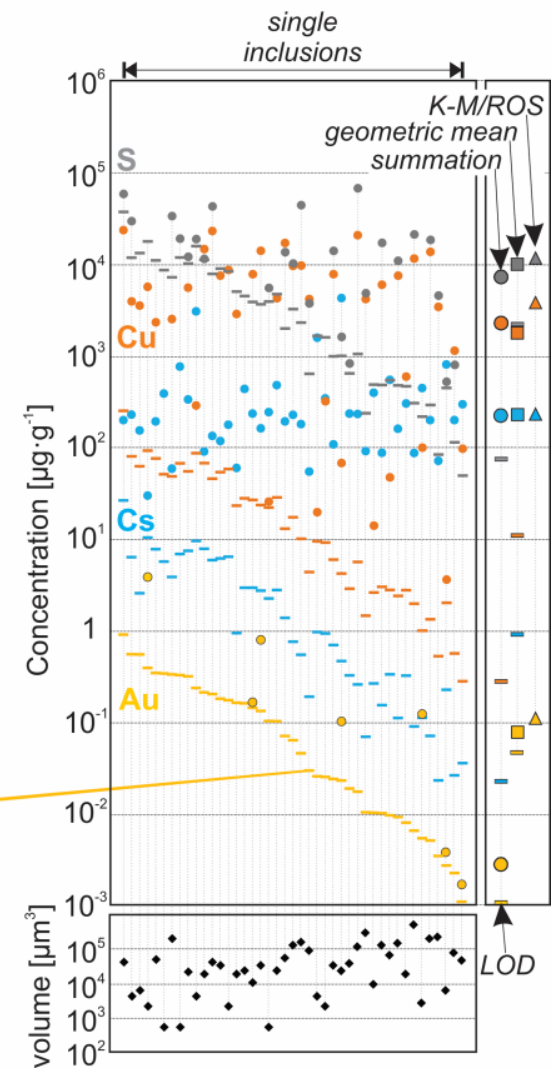

Fig. 6 Comparison of (a) single vapor inclusion signal and (b) summation of 44 vapor inclusions from petrographically identical assemblages from a single sample (Mole Granite, Australia). The grey intervals depict the integration intervals for the instrumental background (bgr), the host mineral (host) and the fluid inclusions (FI). (c) Calculated $\mathrm{Au}, \mathrm{Cs}$, $\mathrm{Cu}$, and $\mathrm{S}$ concentrations (dots) and limits of detection (bars) for all 44 inclusions, sorted by decreasing Au LOD, compared to the value returned by summation method (large circles), geometric mean (squares), and K-M or ROS methods (triangles). Inclusion volume (black diamonds) was calculated from measured length and width of the inclusions, with the assumption that the third dimension is the same as the shorter of the two measured parameters.

Table 3. Results of 6 different statistical data treatment methods to estimate average concentration value of fluid inclusion assemblage illustrated in Fig. 6. For details see text.

\begin{tabular}{lllllll}
\hline & $\begin{array}{l}\text { Summation } \\
\text { method }\end{array}$ & $\begin{array}{l}\text { Geometric } \\
\text { mean }\end{array}$ & $\begin{array}{l}\text { Arithmetic } \\
\text { average }\end{array}$ & K-M & ROS & MLE \\
\hline $\mathrm{S}\left[\mathrm{mg} \cdot \mathrm{g}^{-1}\right]$ & 7.6 & 9.9 & 18.4 & 10.9 & 10.8 & 21.1 \\
$\mathrm{Cu}\left[\mu \mathrm{g} \cdot \mathrm{g}^{-1}\right]$ & 2209 & 1750 & 6189 & 5490 & 5491 & 5010 \\
$\mathrm{Cs}\left[\mu \mathrm{g} \cdot \mathrm{g}^{-1}\right]$ & 224 & 234 & 437 & 437 & 437 & 373 \\
$\mathrm{Au}\left[\mu \mathrm{g} \cdot \mathrm{g}^{-1}\right]$ & 0.004 & 0.08 & 0.65 & 0.11 & 0.10 & 0.81 \\
\hline
\end{tabular}

\section{Conclusions}

Laser ablation micro-analysis of trace quantities of elements in fluid inclusions has been improved through advances in the sensitivity of fast-scanning ICP-MS. Making use of these advances depends increasingly on the cleanliness of the host sample and the entire aerosol transport system. We have 
developed a workflow (Fig. 7) that minimizes a series of possible contamination problems, each of which may jeopardize the detection and quantification of elements close to their detection limit, such as gold and sulfur in natural, low-density vapor inclusions.

Sampling gas (6.0 grade $\mathrm{He}$ ) and plasma gas (6.0 grade Ar) are selected for minimal gas blank intensities on the elements of interest, taking into account the variations that are not always specified by the suppliers. The sample chamber must be rigorously cleaned, especially after previous analytical sessions that liberated aerosols rich in trace elements to be analyzed in the inclusions. An all-glass sample chamber is used for ease of cleaning by aqua regia, followed by mild abrasion with A-PA alumina suspension in a slurry of epoxy beads, fully immersed in an ultrasonic agitator. The transport tubing from the sample chamber to the plasma should be trace element-free (e.g. FEP or PTFE), since tube abrasion by the aerosol can contribute to contamination. Sampler and skimmer cones of Ni are found to be pure and able to withstand regular cleaning by HF and A-PA alumina polishing suspension cleaning.

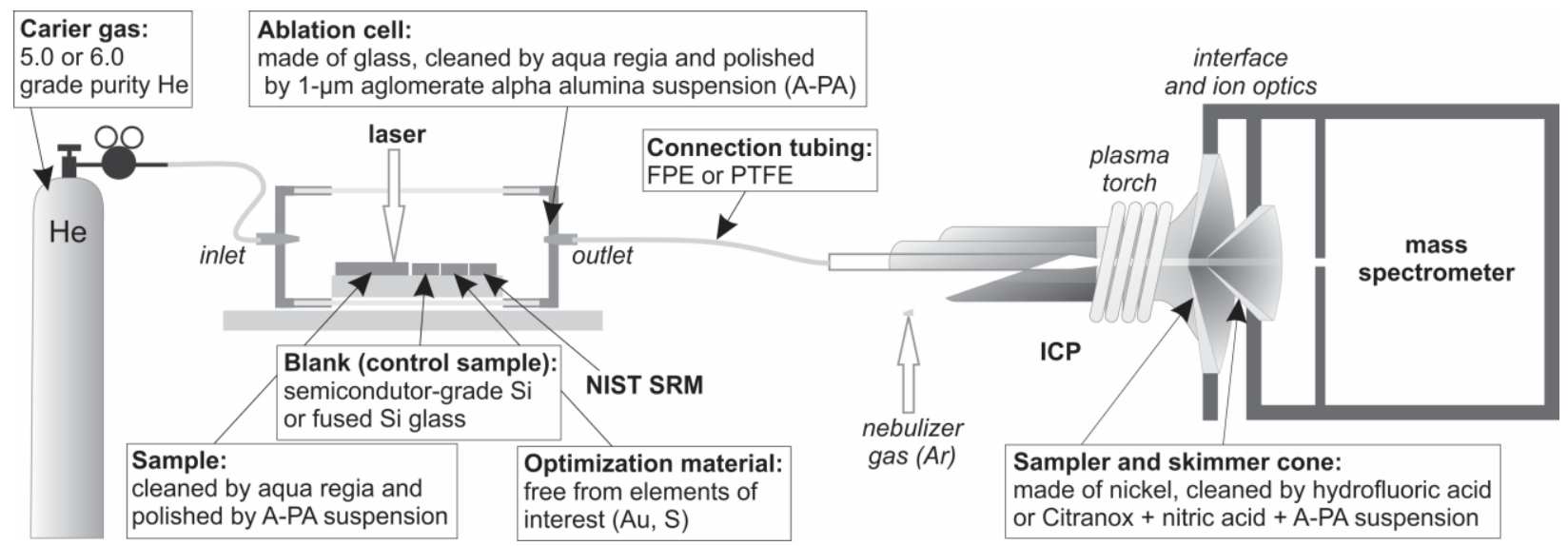

Fig. 7 LA-ICP-MS set-up for analysis of fluid inclusions with recommended cleaning steps and materials. Modified after Günther and Hattendorf 47 . A-PA $=1 \mu \mathrm{m}$ agglomerate alpha alumina suspension.

In preparation for a measurement session with this clean hardware set-up, the sample chips containing the fluid inclusions of interest require chemical, as well as abrasive cleaning subsequent to photographic documentation. A trace element-free tuning material (synthetic U- and Th-doped silicate glass) and a high-purity blank material is loaded together with the sample and a multielement reference material (e.g. NIST SRM glass) into the all-glass sample chamber. In addition, a high-purity blank sample (e.g. semiconductor grade silicon or fused silica glass) is loaded for monitoring any laser-induced desorption of contaminants (notably $\mathrm{S}, \mathrm{Au}, \mathrm{Sn}$ but also $\mathrm{Cl}, \mathrm{Br}, \mathrm{Hg}$, and possibly other elements) from the interior of the sample chamber and the transport system. The ICPMS is tuned on the U-Th-doped glass for optimized sensitivity and oxide formation rate. Only short ablations of the reference material $(20 \mathrm{~s})$ are then used for external standardization, in order to minimize spraying the sample chamber and transport system with elements that commonly are present in much greater quantities in the reference materials compared with those contained in the fluid inclusions. Laser shots on the high-purity blank are then used to check for inacceptable memory effect on critical elements that may be desorbed from the interior of the sample chamber by the UV laser or abraded from the transport system by the aerosol. The surface of each fluid inclusion targeted for analysis is ablated by cleaning laser shots, with a pit diameter exceeding the final surface diameter needed for complete ablation of the inclusion from the conical crater, until all debris from previous inclusion ablations is removed. The cleaning ablation shots should be also recorded for 
control. After re-focusing to the lowered sample surface, the inclusion is ablated starting with a small pit diameter that is gradually increased by an iris diaphragm in the UV imaging path to fully cover and completely ablate the inclusion. An example of clean and reliable fluid inclusions analysis is depicted in Fig. $2 b$.

Data reduction follows previously published routines ${ }^{16-18}$, placing special attention to the subtraction of the host baseline before and preferably also after excavating the inclusion, in order to correct for elements that are contained in the host mineral or any residual memory contaminations. Multiple analyses in an assemblage of coeval inclusions are required for obtaining statistically valid compositions of paleo-fluids, for quantifying the uncertainty of consistently detected element concentrations and for critically estimating upper limits of element concentrations that are not detected or detected only in some of the individual inclusion analyses. Data interpretation requires a case by case assessment, taking into account the physical reasons for signal variations, e.g. imperfect laser sampling of inclusions containing heterogeneously entrapped microparticles. Summation of the low-count signals from petrographically well-constrained fluid inclusions in an assemblage can amplify such signals and provide more representative average concentration values for fluid inclusions from a given population.

\section{Acknowledgements}

We acknowledge the financial support by the Swiss National Science Foundation (SNF/Project 200021-146651), and the help of Ying-Jui Hsu and David Dolejš with preparation of the new optimization material. We greatly appreciate discussions with Marcel Guillong, Oscar Laurent, Zoltan Zajacz, Andreas Audétat, Tobias Fusswinkel, Thomas Wagner, and Julien Mercadier, which helped improving the analytical procedure and the presentation of this paper. We thank two anonymous reviewers for their constructive comments and Nathalie Lefebvre for proof reading the manuscript. 


\section{References}

1. R. H. James and H. Elderfield, Geology, 1996, 24, 1147-1150.

2. A. Audétat, D. Günther and C. A. Heinrich, Science, 1998, 279, 2091-2094.

3. T. Ulrich, D. Günther and C. A. Heinrich, Nature, 1999, 399, 676-679.

4. $\quad$ S. F. Simmons and K. L. Brown, Science, 2006, 314, 288-291.

5. J. J. Wilkinson, B. Stoffell, C. C. Wilkinson, T. E. Jeffries and M. S. Appold, Science, 2009, 323, 764-767.

6. M. M. Allan, G. W. Morrison and B. W. D. Yardley, Econ Geol, 2011, 106, 413-436.

7. $\quad$ S. E. Kesler, R. J. Bodnar and T. P. Mernagh, Geofluids, 2013, 13, 398-404.

8. J. Hammerli, B. Rusk, C. Spandler, P. Emsbo and N. H. S. Oliver, Chem Geol, 2013, 337, 75-87.

9. R. J. Bodnar, P. Lecumberri-Sanchez, D. Moncada and M. Steele-MacInnis, in Treatise on Geochemistry (Second Edition), ed. H. D. H. K. Turekian, Elsevier, Oxford, 2014, pp. 119-142.

10. S. E. Jackson, B. J. Fryer, W. Gosse, D. C. Healey, H. P. Longerich and D. F. Strong, Chem Geol, 1990, 83, 119-132.

11. H. P. Longerich, S. E. Jackson and D. Günther, J. Anal. At. Spectrom., 1996, 11, 899-904.

12. A. H. Rankin, M. H. Ramsey, B. Coles, F. Vanlangevelde and C. R. Thomas, Geochim Cosmochim Ac, 1992, 56, 67-79.

13. T. J. Shepherd and S. R. Chenery, Geochim Cosmochim Ac, 1995, 59, 3997-4007.

14. T. Wagner, T. Fusswinkel, M. Walle and C. A. Heinrich, Elements, 2016, 12, 323-328.

15. E. Roeder, Fluid inclusions, Mineralogial Society of America, Virginia, USA, 1 edn., 1984.

16. D. Günther, A. Audétat, R. Frischknecht and C. A. Heinrich, J. Anal. At. Spectrom., 1998, 13, 263270.

17. C. A. Heinrich, T. Pettke, W. E. Halter, M. Aigner-Torres, A. Audétat, D. Günther, B. Hattendorf, D. Bleiner, M. Guillong and I. Horn, Geochim Cosmochim Ac, 2003, 67, 3473-3497.

18. T. Pettke, F. Oberli, A. Audétat, M. Guillong, A. C. Simon, J. J. Hanley and L. M. Klemm, Ore Geol Rev, 2012, 44, 10-38.

19. C. Latkoczy and D. Gunther, J. Anal. At. Spectrom., 2002, 17, 1264-1270.

20. M. Wälle and C. A. Heinrich, J. Anal. At. Spectrom., 2014, 29, 1052-1057.

21. J. H. Seo, M. Guillong, M. Aerts, Z. Zajacz and C. A. Heinrich, Chem Geol, 2011, 284, 35-44.

22. A. Stefansson and T. M. Seward, Geochim Cosmochim Ac, 2004, 68, 4121-4143.

23. C. A. Heinrich, T. Driesner, A. Stefansson and T. M. Seward, Geology, 2004, 32, 761-764.

24. G. S. Pokrovski, A. Y. Borisova and J. C. Harrichoury, Earth Planet Sc Lett, 2008, 266, 345-362. 
25. Z. Zajacz, J. H. Seo, P. A. Candela, P. M. Piccoli, C. A. Heinrich and M. Guillong, Earth Planet Sc Lett, 2010, 297, 50-56.

26. M. Guillong, C. Latkoczy, J. H. Seo, D. Günther and C. A. Heinrich, J. Anal. At. Spectrom., 2008, 23, 1581-1589.

27. T. Prohaska, C. Latkoczy and G. Stingeder, J. Anal. At. Spectrom., 1999, 14, 1501-1504.

28. E. M. Ripley, C. S. Li, C. H. Moore, E. R. Elswick, J. B. Maynard, R. L. Paul, P. Sylvester, J. H. Seo and N. Shimizu, Rev Mineral Geochem, 2011, 73, 9-39.

29. A. C. Simon, M. R. Frank, T. Pettke, P. A. Candela, P. M. Piccoli and C. A. Heinrich, Geochim Cosmochim Ac, 2005, 69, 3321-3335.

30. J. J. Hanley, T. Pettke, J. E. Mungall and E. T. C. Spooner, Geochim Cosmochim Ac, 2005, 69, 2593-2611.

31. A. C. Simon, T. Pettke, P. A. Candela, P. M. Piccoli and C. A. Heinrich, Geochim Cosmochim Ac, 2007, 71, 1764-1782.

32. Z. Zajacz, P. A. Candela, P. M. Piccoli, M. Wälle and C. Sanchez-Valle, Geochim Cosmochim Ac, 2012, 91, 140-159.

33. J. H. Seo and C. A. Heinrich, Geochim Cosmochim Ac, 2013, 113, 60-69.

34. P. Koděra, C. A. Heinrich, M. Wälle and J. Lexa, Geology, 2014, 42, 495-498.

35. K. Rauchenstein-Martinek, T. Wagner, M. Wälle and C. A. Heinrich, Chem Geol, 2014, 385, 7083.

36. M. F. Márquez-Zavalía and C. A. Heinrich, Mineralium Deposita, 2016, 51, 873-902.

37. G. S. Pokrovski, N. N. Akinfiev, A. Y. Borisova, A. V. Zotov and K. Kouzmanov, Geol Soc Spec Publ, 2014, 402, 9-70.

38. M. Tanner, J. Anal. At. Spectrom., 2010, 25, 405-407.

39. A. Ulianov, O. Muntener, U. Schaltegger and F. Bussy, J. Anal. At. Spectrom., 2016, 31, 597-630.

40. D. Günther, R. Frischknecht, C. A. Heinrich and H. J. Kahlert, J. Anal. At. Spectrom., 1997, 12, 939-944.

41. D. Günther and C. A. Heinrich, J. Anal. At. Spectrom., 1999, 14, 1363-1368.

42. M. Guillong and D. Günther, J. Anal. At. Spectrom., 2002, 17, 831-837.

43. M. Ortelli, PhD thesis, University of Geneva, 2015.

44. M. Guillong, D. L. Meier, M. M. Allan, C. A. Heinrich and B. W. D. Yardley, Mineralogical Association of Canada, Short Course Series, 2008, 40, 323-333.

45. N. J. G. Pearce, W. T. Perkins, J. A. Westgate, M. P. Gorton, S. E. Jackson, C. R. Neal and S. P. Chenery, Geostandard Newslett, 1997, 21, 115-144.

46. C. E. McGinnis, J. C. Jain and C. R. Neal, Geostandard Newslett, 1997, 21, 289-305. 
47. D. Günther and B. Hattendorf, Trac-Trend Anal Chem, 2005, 24, 255-265.

48. A. Audétat, D. Günther and C. A. Heinrich, Econ Geol, 2000, 95, 1563-1581.

49. R. Seltmann, A. Bankwitz, A. Frischbutter and R. Thomas, in Proceedings of the 1st International Conference on the Bohemian Massif, ed. Z. Kukal, Czech Geological Survey, 1988, pp. 257268.

50. B. Lahl, Königliche Topase vom Schneckenstein Edelsteine aus dem Vogtland, Chemnitzer Verlag, Chemnitz, 2012.

51. T. W. May and R. H. Wiedmeyer, Atom Spectrosc, 1998, 19, 150-155.

52. E. H. Evans and J. J. Giglio, J. Anal. At. Spectrom., 1993, 8, 1-18.

53. M. Guillong and C. A. Heinrich, J. Anal. At. Spectrom., 2007, 22, 1488-1494.

54. A. J. Kidnay, W. R. Parrish and D. G. McCartney, Fundamentals of natural gas processing, CRC Press, Boca Raton, FL, 2nd edn., 2011.

55. L. M. Klemm, PhD thesis, DISS. ETH Nr. 16395, ETH Zurich, 2006.

56. R. J. Lewis and G. G. Hawley, Hawley's condensed chemical dictionary, Wiley, Hoboken, N.J., 15 th edn., 2007.

57. M. Guillong and T. Pettke, J. Anal. At. Spectrom., 2012, 27, 505-508.

58. D. R. Helsel, Statistics for censored environmental data using Minitab and R, Wiley, Hoboken, N.J., 2nd edn., 2012. 